A complete discussion of intellectual property (IP), faculty rights, and the public good requires a thorough framing of higher education's legal context, from which the rise of legalistic criteria (or legalization) and current IP regime have grown.

\title{
1
}

\section{The Legalization of Higher Education}

\section{Lara K. Badke}

Colleges and universities operate in a complex and ever-changing legal environment, with constraints and opportunities shaped by legal considerations significant factors in organizational functioning and campus relationships (Alger, 2008; Gajda, 2009; McLendon \& Hearn, 2006; Olivas, 2005; Toma, 2011). Contemporary intellectual property issues in higher education, centered on the ownership and commodification of knowledge, often conflict with inherent and traditional notions of instructional and scholarly knowledge. The economic, political, and social pressures shaping intellectual property debates combine with legal forces to influence higher education policy and practice. With nearly every activity engaged in by university students, faculty, and staff involving the production or use of original expression (copyright), invention (patent), or brand (trademark), each of which is capable of imparting ownership and profit opportunities, it is impossible for academe to escape intellectual property's reach (Pauken, 2009; Sun \& Baez, 2009; Toma, 2011).

Questions of ownership between faculty and their institutions, as well as between academe and industry, are growing more complicated and more contentious. Developing, licensing, and protecting intellectual property rights in higher education often pits individual interests (primarily tied to matters of making, owning, distributing, and capitalizing on knowledge and invention), public interests (consumption of the intellectual good or service), and institutional interests (enabling the commercialization of research, teaching, and other scholarly activities) against each other (Pauken, 2009; Sun \& Baez, 2009; Toma, 2011). A prevailing tension, for example, relates to whether inventions should exist to serve society or create economic gain, or even whether these interests are mutually exclusive (American Association for the Advancement of Science, 1934; Mowery \& Sampat, 2001; Parthasarathy, 2014). As the nature of faculty work and academic research transform higher education, core values, assumptions, and functions of the modern American university are challenged (McGee \& Diaz, 2005; Olivas, 2005; Ross, 2012; Slaughter \& Leslie, 1997; Slaughter \& Rhodes, 2004; Sun \& Baez, 2009; Toma, 2011; Welsh, 2000).

The purpose of this chapter is to provide an orientation to the broad legal context shaping the field of modern higher education, linking the legalization of higher education - of which intellectual property is a part-to an environment of diminished academic freedoms and judicial deference to academe. The striking shift of judicial attitudes toward scholarly disputes, including the burgeoning disagreements in assigning ownership and specifying permissible use of ideas, threatens to further restrict the pursuit and transmission of knowledge at the very heart of higher education (Gajda, 2009; McSherry, 2001). By examining significant developments giving rise to the legalization of higher education, the conditions underlying current intellectual property debates and rights can be better understood. Understanding how academic values are diminished as

This is the author manuscript accepted for publication and has undergone full peer review but has not been through the copyediting, typesetting, pagination and proofreading process, which may lead to differences between this version and the Version of Record. Please cite this article as doi: 10.1002/he.20222.

This article is protected by copyright. All rights reserved. 
legal scrutiny of university affairs rises is important to the considerations of the intellectual property concerns explored in detail in subsequent chapters.

This chapter surveys social, political, and economic dimensions contributing to the legalization of higher education. I begin by introducing higher education's role as supplier of intellectual property through research, scholarship, and the dissemination of knowledge. Here I consider how higher education's increasingly marketoriented focus has influenced its legal environment. Next I examine threats of this market orientation to higher education's central values. I argue that as universities begin to operate more like businesses, judicial deference to academic expertise weakens university autonomy. In the next section I trace the evolution of the legalization of higher education. Highlighting ongoing tensions between outside legal forces and university self-determination, I relate the expanding relationship between the courts and higher education to concerns over intellectual property rights. I then address consequences of the entrepreneurial university on university functioning, particularly through faculty workforce reorganization. In the final section of the chapter, I extend some observations on the importance of intellectual property rights to higher education in a democratic society. I offer these insights to facilitate a greater understanding of the legal environment in which complex intellectual property right debates take place. With the entrepreneurial university bringing academics into more frequent contact with commercial partners and complex laws, and intellectual property as a moneymaker to universities showing no signs of decline, increasing our understanding of the university's legal environment is fundamental to staving off additional threats to academe's defining values.

\section{Legalization and Universities' Growing Business Orientation}

Debate abounds surrounding a sense of abandonment of universities' public identity and mission from the rise of a market-oriented university model (Bok, 2003; Gajda, 2009; Lake, 2010; Olivas, 2005; Slaughter, 2001; Slaughter \& Leslie, 1997). In addition to raising questions as to the nature and extent of a social compact between universities and society, the commercialization of higher education has been linked with a loss of judicial deference to academic self-governance and academic freedom (Gajda, 2009; Olivas, 2005; Toma, 2011). Though not new, a legalistic environment in higher education-characterized by standardized rule making, the adoption of formal practices, dominance of legalistic decision criteria, heightened concern over litigation, and use of legalistic rhetoric -is on the rise (Edelman \& Suchman, 1997; Gajda, 2009; McSherry, 2001; Meyer, 1983; Selznick, 1969; Sitkin \& Bies, 1994; Toma, 2011; Weber, 1947). Intellectual property, for example, in which universities seek legal protection over their ideas and brand, is an undeniable strategic asset now occupying a coveted role in the new American university (Bok, 2003; Kirp, 2003; Rhodes, 2001). Given the high stakes involved in legal claims over ownership and other commercial rights relating to intellectual property issues, the impact of legalistic influences on organizational processes and structures, often described as legalization, is inevitable (Meyer, 1983; Scott, 1994; Selznick, 1969; Sitkin \& Bies, 1994).

Federal policy and a series of court rulings stressing accountability and consumer protection have contributed to this legalized environment, resulting in a tightening of fair use exceptions and shrinking of the public domain. Fair use, essentially the legal use of copyrighted material for a limited and transformative purpose (17 U.S. Code $§ 107-$ Limitations on exclusive rights: Fair use), has been vaguely defined to enable it to evolve based on changing conditions (Stim, 2010). Works in the public domain are not restricted by copyright, either having never been copyrighted or whose copyright has expired. Such works do not require a license or fee to use. Examples would include the Bible, Mozart's compositions, and mathematical formulae (Stim, 2010). The combination of increasingly restrictive fair use exceptions and a dwindling public domain result in common scholarly materials becoming less accessible and conflicts of interest between public benefit

This article is protected by copyright. All rights reserved. 
and creator control intensifying (Sun \& Baez, 2009; Toma, 2011). To hinder further encroachment on academic values, it is imperative to understand the law's influence on higher education in an increasingly commercialized environment.

\section{1 \\ Legalization's Encroachment on University Autonomy}

Where traditionally courts once steered clear of academic matters, allowing faculty and deans the autonomy to manage internal university affairs, regulatory and legal scrutiny now permeate nearly all aspects of university functioning (Gajda, 2009; Olivas, 2013; Toma, 2011). Between 1997 and 2012 alone, federal regulations of higher education jumped by $56 \%$ (American Council on Education, 2015). Legal encroachment into academic matters is considered to be-along with globalization, increased competition, economic pressures, and workforce restructuring - a key contributor to the profound shifts in nature, structure, and values of the modern American university (Ayers, 2005; Gumport, 1993; Paulson \& St John, 2002; Saunders, 2010; Slaughter \& Rhoades, 2004; Tierney, 1998; Zusman, 2005). Each of these factors has driven university operations and faculty pursuits beyond once central purposes of instruction and scholarship to involvement in market-like behaviors and commercial exploitation of knowledge (Gajda, 2009; Slaughter \& Rhoades, 2004).

The infusion of such practices into academic research eroded distinctions that once existed between the academic world and the corporate sector. One consequence of this transformation was that courts became less apt to recognize the professional judgment of educators or defer to institutional autonomy in resolving disputes (Gajda, 2009; Olivas, 2013; Toma, 2011). Offsetting fading state financial support of higher education, universities continued down the path of commercial expansion (Archibald \& Feldman, 2006; Cameron, 1983; Gajda, 2009; Paulson \& St John, 2002; Saunders, 2010; Slaughter \& Rhoades, 2004; Zusman, 2005). The result? Commercial practices on campus grew to an unprecedented size and scope (Bok, 2003; Gajda, 2009; Kirp, 2003; Lake, 2010). The number of patents granted to academic institutions jumped by 1,325\% between 1979 and 2000, far exceeding the growth of patents generally (Raj, 2004). While patent licensing in 1991 generated revenue of $\$ 123$ million for universities, by 2006 that figure had soared to $\$ 1.2$ billion (Bagley, 2006), with licensing income in 2011 reaching \$2.5 billion (autm.net, 2011 Licensing Activity Survey). With an intensifying consumer orientation to higher education as a private good available for purchase further driving commercial expansion, modern day universities have been transformed into immense corporate businesses (Bickel \& Lake, 1999; Bok, 2003; Gajda, 2009; Kaplin \& Lee, 2006; Lake, 2010; Marske \& Vago, 1980; Olivas, 2000, 2005; Saunders, 2010; Slaughter, 2001; Slaughter \& Leslie, 1997; Toma, 2011). One of the inevitable results of this shift: a watershed juncture between campus and courts leading to an increase in the legalization of higher education.

The term legalization has been treated with different and sometimes conflicting connotations (Friedman, 1975; Meyer, 1981, 1983; Roth, Sitkin, \& House, 1994; Scott, 1994; Selznick, 1969; Sitkin \& Bies, 1993, 1994; Weber, 1947; Yudof, 1981). Drawing on the work of organizational scholars who examined the close association of law and organizations, legalization can be understood to refer to the acts of outside forces (traditionally presented in the guise of legislation, regulation, and litigation) that affect the organization (such as ownership over courseware and scholarly research articles), and those in it (faculty, students, administrators), in relation to its legal culture and environment (balancing of rights as knowledge assets are produced, protected, and made profitable) (Selznick, 1969; Sitkin \& Bies, 1994). Such outside acts often transcend routine compliance with legal requirements (for example, exceeding responsibilities under the Copyright Act) and create opposition between education and society (questioning whether academic inventions should serve a public good or proprietary financial gain) (Jasanoff, 1985; Meyer, 1981, 1983).

This article is protected by copyright. All rights reserved. 
Further complicating the legal environment in higher education are new and unsettling forms of informal lawmaking. Policy making initiated through ballot initiatives, insurance policy restrictions, and commercial law practices transform an already volatile legal landscape, with universities having to understand and adapt to additional legal obligations (Olivas, 2000, 2005, 2013; Toma, 2011).

\section{Evolution of the Legalization of Higher Education}

Literature addressing the phenomenon of legalization in higher education reveals a strong historical inclination by the courts to steer clear of campus disputes (ownership of course materials for example), allowing universities to manage their own affairs (Gajda, 2009; Kaplin, 1985; Munn, 1998). Routine academic disputes were settled internally among a community of scholars with high degrees of personal interaction, organizational purpose, and shared professional norms and values (Berdhahl, 1991; Burnett \& Matthews, 1982; Gajda, 2009; Goodman, 1962; Hardy, 1992; Kaplin, 1985; Millett, 1962; Munn, 1998; Warters, 1998). Higher education was considered a unique enterprise "far too delicate and complex for involvement by outsiders" (Munn, 1998, p. 36) who would "be ignorant of the special agreements and sensitivities underpinning [the academic] environment" (Kaplin, 1985, p. 4). Federal and state governments were reluctant to establish laws, regulations, or obligations that directly impacted the daily operations of a university (Gajda, 2009; Munn, 1998). Institutional management was effectively maintained through normative practice and consensual agreement. Today, fueled by a weakened social compact between universities and society, diminished respect for university decision-making autonomy, and an individual rights mindset, a remarkable number of disagreements in academe end up in court, displacing academic judgment in internal affairs with that of a judge or jury (Gajda, 2009; Helms, 1987; Munn, 1998; Schauer, 2006; Yudof, 1981).

A shift in legislative and judicial attitudes toward higher education rapidly expanded with growing civil rights awareness (Bickel \& Lake, 1999; Munn, 1998; Yudof, 1981). An increase in student rights, campus protests, and organizing movements created a shift in collegial and deferential attitudes, and an inundation of lawsuits demanding judicial review of university decisions. Courts became forums for novel causes of litigation not heard of a decade earlier, such as complaints over grades, tenure denial, even office allocation (Burnett \& Matthews, 1982; Gajda, 2009). Broader and less welcome forms of judicial oversight of university decisions had begun. These were most apparent in the growing duty placed upon the university in the form of contract law (a student arguing she or he did not receive the quality of education paid for, for example) and tort law (a professor's conduct or an unreasonable university policy causing a student harm). University management was subjected to greater scrutiny from its constituents, who turned to the courts to voice their objections to academic differences. Where academic abstention doctrines once protected university decision-making autonomy, judges were now increasingly receptive to mediating campus conflicts (Gajda, 2009; Lake, 2005).

Following an era of unprecedented civil rights, affirmative action, political discontent, and judicial battles over campus management pitting universities against students, the 1980s ushered in additional legalization by stepping up legislative reforms and expanding individuals' standing to sue universities. Of particular relevance to the evolution of intellectual property rights in higher education was the introduction in 1980 of the Bayh-Dole Act and amendments to the Copyright Act (Sun \& Baez, 2009). Not only was the growth and profitability of computer software exploding as the Patent and Trademark Office began issuing patents to software, but universities could now also patent and license the results of federally funded research. Prior to the Bayh-Dole legislation, the rights to inventions created with federal funding remained with the government, who licensed fewer than 5\% of patentable inventions (Schacht, 2000). Proponents of the Bayh-Dole Act argued that the results of university-based discoveries could promote the public good by improving lives, encouraging

This article is protected by copyright. All rights reserved. 
innovation, promoting the progress of science, increasing competition, and stimulating the economy. The legislation ultimately created new pathways and financial incentives for universities to commercialize their research (S. Rep. No. 96-480, 1979; 35 USC § 200). This regulation for the "public good" was not without ulterior motives. Congress was concerned at the time with a stagnant economy and declining industrial competitiveness (Stevens, 2004). Universities found themselves a convenient target in the economic and political arguments for change.

Continuing legislative reforms coupled with precedent setting cases of aggrieved parties resorting to courts to resolve intellectual property disputes resulted in a growing "propertization" of academic work (Gajda, 2009; McSherry, 2001). The 1989 New York federal appeals case of Weissmann v. Freeman, for example, illustrated a marked shift of judicial attitudes in academic disputes. The trial court dismissed the dispute, over scholarly credit between a junior associate and her prominent mentor, based on academic norms. The court determined the root cause of the dispute to be misguided ego, and argued such academic quarrels did not belong in the courts. The appellate court, however, overruled the lower court's deference to academic norms and strictly applied the Copyright Act to the authorship dispute. It also recognized academic identity as property. Extending the exchange and ownership of knowledge beyond patents and copyright, Weissmann introduced a new academic property claim of name and identity misappropriation (unauthorized use of a scholar's valuable identity). Essentially, the court broadened the causes of action in which customary norms of academic collaboration could be challenged (Gajda, 2009; McSherry, 2001; Weissmann, 1989). This propertization of academic work, aptly illustrated in modern lawsuits questioning ownership of lecture materials (by professor, institution, or student), for example, situates scholarship and pedagogy at the center of a market economy that allows courts the leeway to assign ownership and specify permissible uses of ideas and knowledge at the heart of the academic enterprise (Blumenstyk, 1999; Gajda, 2009; McSherry, 2001). The changing circumstances influencing ownership rights to academic work did not occur in a vacuum. Concurrently, other pressures were contributing to higher education's market transformation in which intellectual property, once regarded in academe as a necessary evil, evolved as a virtue and institutional moneymaker (Bok, 2003; Gajda, 2009; Kirp, 2003).

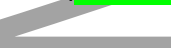

\section{Effects of the Entrepreneurial University}

As increasing importance was placed on universities to bring innovations to market, a shift in university culture began. The massification of higher education brought increased enrollments, expanded the number and type of learning institutions, and saw increases in federal research funding. Whereas a societal benefit of higher education was to educate the masses on the one hand, public financial support was being withdrawn on the other. Between 1980 and 1993, state funding for public institutions fell by $8.8 \%$. Government funding as a percentage of all revenue sources for higher education declined by almost 10\% (Gumport, lannozzi, Shaman, \& Zemsky, 1997). The steady decline in government support necessitated that universities develop distinctive niches and become self-supporting. Revenue generation and entrepreneurial ambition fueled the expansion of inventions, virtual education, and corporate partnerships. As university research became more commodified, commercial practices on campus swelled, enabling universities to pursue their academic missions through external financing and expansion. This move toward academic capitalism had the unforeseen effects of fueling workforce reform and contributing to the growing legalization of higher education (Gajda, 2009; Olivas, 2005; Rhoades, 1996; Slaughter, 2001; Somers \& Somers-Willett, 2002).

This article is protected by copyright. All rights reserved. 
Heightened research pressures and teaching loads were transforming faculty structures. Not only were entrepreneurial expectations of faculty rising, but the organizational complexity to manage research programs and functions was rapidly expanding (Gumport et al., 1997). Changes to faculty composition became a contributing factor in the shift in organizational control away from faculty toward administrators. Shared governance and collegial decision making, systems characteristic of higher education prior to the growth of late modernity, had given way to more hierarchical and political decision making models (Kezar \& Eckel, 2004; Saunders, 2010). As the nature of faculty work and faculty composition changed from tenure-track faculty engaged simultaneously in teaching, research, and service to nontenure track teaching or research or serviceonly roles, the market-driven transformation of academic work created a stratification in academic employment and job security (Rhoades, 2004; Saunders, 2010; Toma, 2011).

Across the field as a whole, tenured professors began to slowly disappear from the higher education landscape, with nontenure track adjuncts outnumbering their tenured colleagues' ranks (Donoghue, 2008). The tightening academic job market, in conjunction with power imbalances, poor working conditions, and few contractual rights created an environment in which contingent faculty had little other recourse than to resort to litigation when aggrieved (Burnett \& Matthews, 1982; Gajda, 2009). Ownership disputes led institutions to argue that work produced within the scope of faculty's paid university employment (known as the work-madefor-hire doctrine) resided with them, the employer, not the faculty member (Toma, 2011). As the number of contingent faculty denied the protection of academic freedom grew, so did the amount of litigation on related issues (Euben, 2004). Administrators were inconsistently applying institutional policies based on faculty rank. Disparity between tenured and contingent faculty created a risk management imperative for the institution. Universities could nolonger demonstrate adherence to their own rules created to safeguard unique academic circumstances. How then could they expect to insulate themselves from the courts on the basis of substantive and procedural fairness? Faculty increasingly turned to the courts to resolve discrimination, First Amendment (academic freedom, free speech), and property claims to assert their rights. These claims opened up new directions for external judicial supervision and control of the intellectual life of a university, further displacing traditional and socially beneficial academic norms of sharing and collaboration (Gajda, 2009; Kezar, Maxey, \& Badke, 2014; Toma, 2011).

\section{Importance of Intellectual Property Rights to Higher Education in a Democratic Society}

The amalgamation of such factors as the commercialization of higher education and transformation of the academic workforce pose threats to academic freedom because of the breakdown in the basic social compact underlying higher education. The effectiveness of the university is premised on a covenant struck between the university and the general public under which society financially supports the university and grants it great autonomy. In return, the university invests its resources and freedoms to serve the larger public interest (Finkin \& Post, 2009; Rhodes, 2001). The public, through government policy, has seemingly broken its end of the bargain by withdrawing financial support and increasing regulatory oversight. Universities have adapted by raising tuition and brokering new commodities-everything from patents to executive education partnerships-resulting in a sense of abandonment of their public identity and mission. Institutional policies developed in support of this entrepreneurial direction often create a chilling effect on academic freedom under the guise of "innovation" (Toma, 2011). Abandoning the public purpose that once personified research universities, academic freedom rights to pursue controversial work diminish in favor of entrepreneurial 
ambition. Such threats to academic freedom are particularly acute with an increasing number of contingent faculty operating with neither constitutional nor contractual protections. Tenured faculty are also not immune to shifts in academic freedom protections, with course content and delivery undermined as work-for-hire within the scope of employment shifts ownership rights to the university. Balancing the legitimate interests of all stakeholders - the public's use and enjoyment of content, the university's efforts to advance innovation and seek new funding streams, faculty's right to their own work and creations-are further complicated as traditional rights of self-governance face the rising tide of courts asserting themselves into the once unique environment of academic judgments (Gajda, 2009; Toma, 2011).

In today's increasingly regulated and commercialized academic environment, universities' potential liability for infringement of intellectual property rights looms large. The line between fair use of copyrighted material and copyright infringement, for example, is precarious. Universities must simultaneously balance moral and pecuniary rights of scholarship and intellectual property with monitoring and enforcement obligations, such as removal of materials once the institution is informed of copyright infringement (Toma, 2011). Universities possess the power to influence legal compliance and shape norms as they select, interpret, and challenge laws (Edelman, Fuller, \& Mara-Drita, 2001; Edelman, Leachman, \& McAdam, 2010; Edelman \& Suchman, 1997; Scott, 1994; Suchman \& Edelman, 1996). If universities fail to influence the progression of intellectual property laws and practices that affect higher education and its interests, rival groups' (pharmaceutical companies influencing programs for the continuing education of medical practitioners, for example; or technology companies specializing in Internet-related services owning and controlling knowledge) ability to shape the law for purposes other than to advance teaching, learning, and research strengthens. The evolution of the legalization of higher education paints a picture of a higher education landscape marked by increasingly divisive interests, polarizing events, legal pressures, and threats to academic values. With changes in the legal environment creating incentives for competitive advantage (Bagley 2008, 2010; Bird, 2008, 2011), it is incumbent upon higher education to advocate on behalf of the importance of intellectual property rights to the critical roles of teaching, learning, and research in a democratic society. Without taking such a proactive stand, the free and open exchange of ideas underlying higher education's central values risk further erosion as the intrusion of outside forces that affect the organization, and those in it, in relation to its legal culture and environment, continues to grow.

\section{References}

American Association for the Advancement of Science. (1934). The protection by patents of scientific discoveries. New York, NY: Author.

American Council on Education. (2015). Recalibrating regulation of colleges and universities: Report of the Task Force on Federal Regulation of Higher Education. Washington, DC: Author.

http: //www.acenet.edu/news-room/Documents/Higher-Education-RegulationsTask-Force-Report.pdf

Alger, J. A. (2008). Legal issues for academic leaders. Effective Practices for Academic Leaders, 3(2), 1-14. Archibald, R. B., \& Feldman, D. H. (2006). State higher education spending and the tax revolt. The Journal of Higher Education, 77(4), 618-644.

Ayers, D. F. (2005). Neoliberal ideology in community college mission statements: A critical discourse analysis. The Review of Higher Education, 28(4), 527-549.

Bagley, M. A. (2006). Academic discourse and proprietary rights: Putting patents in their proper place. Boston College Law Review, 47, 217-274.

Bagley, C. E. (2008). Winning legally: The value of legal astuteness. The Academy of Management Review, 33(2), 378-390.

Bagley, C. E. (2010). What's law got to do with it? Integrating law and strategy. American Business Law Journal, 47, 587-639.

Berdhahl, R. O. (1991). Shared academic governance and external constraints. In M. W. Peterson, E. E. Chaffed, \& T. H. White (Eds.), Organization and academic governance in higher education (4th ed.). Needham Heights, MA: Ginned Press.

This article is protected by copyright. All rights reserved. 
Bickel, R. D., \& Lake, P. F. (1999). The rights and responsibilities of the modern university: Who assumes the risks of college life? Durham, NC: Carolina Academic Press.

Bird, R. C. (2008). Pathways of legal strategy. Stanford Journal of Law, Business \& Finance, 14(1), 1-41.

Bird, R. C. (2011). Law, strategy and competitive advantage. American Business Law Journal, 47.

Blumenstyk, G. (1999, October 1). Putting class notes on the web: Are companies stealing lectures? The Chronicle of Higher Education, A31.

Bok, D. (2003). Universities in the marketplace: The commercialization of higher education. Princeton, NJ: Princeton University Press.

Burnett, C. W., \& Matthews, W. L. (1982). The legalistic culture in American higher education. College and University, 57(2), 197-207.

Cameron, K. (1983). Strategic responses to conditions of decline: Higher education and the private sector. The Journal of Higher Education, 54(4), 359-380.

Donoghue, F. (2008). The last professors: The corporate university and the fate of the humanities. New York, NY: Fordham University Press.

Edelman, L. B., Fuller, S. R., \& Mara-Drita, I. (2001). Diversity rhetoric and the managerialization of law. American Journal of Sociology, 106(6), 1589-1641.

Edelman, L. B., Leachman, G., \& McAdam, D. (2010). On law, organizations, and social movements. The Annual Review of Law and Social Science, 6, 653-658.

Edelman, L. B., \& Suchman, M. C. (1997). The legal environment of organizations. Annual Review of Sociology, 23, 479-515.

Euben, D. R. (2004). Legal watch: Contingent faculty and the courts. Academe.

http: / / www . aaup.org/AAUP/pubsres/academe/2004/JF/Col / lw.htm

Finkin, M. W., \& Post, R. C. (2009). For the common good: Principles of American academic freedom. New

Haven, CT: Yale University Press.

Friedman, L. M. (1975). The legal system: A social science perspective. New York, NY: Russell Sage

Foundation.

Gajda, A. (2009). The trials of academe: The new era of campus litigation. Cambridge, MA: Harvard University Press.

Goodman, P. (1962). The community of scholars. New York, NY: Random House.

Gumport, P. (1993). The contested terrain of academic program reduction. The Journal of Higher Education, 64, 283-311.

Gumport, P. J., Iannozzi, M., Shaman, S., \& Zemsky, R. (1997). Trends in United States higher education:

From massification to post massification. National Center for Postsecondary Improvement. Stanford University. http://web.stanford.edu/group/ncpi/documents/pdfs/1-04 massification.pdf

Hardy, C. (1992). Retrenchment strategies in two Canadian universities: A political analysis. Canadian Journal of Administrative Sciences, 9(3), 180-191.

Helms, L. B. (1987). Patterns of litigation in postsecondary education: A case law study. Journal of College and University Law, 14(1), 99-119.

Jasanoff, S. (1985). The misrule of law at OSHA. In D. Nelkin (Ed.), The language of risk: Conflicting perspectives on occupational health (pp. 155-177). Beverly Hills, CA: Sage.

Kaplin, W. A. (1985). The law of higher education: A comprehensive guide to legal implications of administrative decision making (2nd ed.). San Francisco, CA: Jossey-Bass.

Kaplin, W. A., \& Lee, B. A. (2006). The law of higher education (4th ed.). San Francisco, CA: Jossey-Bass. Kezar, A. J., \& Eckel, P. D. (2004). Meeting today's governance challenges: A synthesis of the literature and examination of a future agenda for scholarship. The Journal of Higher Education, 75(4), 371-399.

Kezar, A., Maxey, D., \& Badke, L. (2014). The imperative for change: Fostering understanding of the necessity of changing non-tenure-track faculty policies and practices. The Delphi Project on the Changing Faculty and Student. http://www.uscrossier.org/pullias/wp-

content/uploads/2013/02/IMPERATIVE-FOR-CHANGE WEB.pdf

Kirp, D. L. (2003). Shakespeare, Einstein, and the bottom line: The marketing of higher education. Cambridge, MA: Harvard University Press.

Lake, P. F. (2005). Private law continues to come to campus: Rights and responsibilities revisited. Journal of College and University Law, 31, 621.

Lake, P. F. (2010, December 5). What's next for private universities? Accountability. The Chronicle of Higher Education. http://chronicle.com/article/Whats-Next-for-Private/125599/

Marske, C. E., \& Vago, S. (1980). Law and dispute processing in the academic community. Judicature, 64(4), 165-175.

McGee, P., \& Diaz, V. (2005). Planning for the digital classroom and distributed learning: Policies and planning for online instructional resources. Planning for Higher Education, 33(4), 12-24.

This article is protected by copyright. All rights reserved. 
McLendon, M. K., \& Hearn, J. C. (2006). Mandated openness in public higher education: A field study of state sunshine laws and institutional governance. Journal of Higher Education, 77(4), 645-683.

McSherry, C. (2001). Who owns academic work? Battling for control of intellectual property. Cambridge, MA: Harvard University Press.

Meyer, J. W. (1981). Organizational factors affecting legalization in education (Report No. IFG-PR-81-B10). Stanford, CA: Institute for Research on Educational Finance and Governance.

Meyer, J. W. (1983). Organizational factors affecting legalization in education. In J. W. Meyer \& W. R. Scott (Eds.), Organizational environments: Ritual and rationality (pp. 217-232). San Francisco, CA: Jossey-Bass. Millett, J. D. (1962). The academic community. New York, NY: McGraw-Hill.

Mowery, D. C., \& Sampat, B. N. (2001). Patenting and licensing university inventions: Lessons from the history of the Research Corporation. Industrial and Corporate Change, 10(2), 317-355.

Munn, R. L. (1998). The attorney-administrator relationship: A perspective on institutional decision making and power. NASPA Journal, 36(1), 35-47.

Olivas, M. A. (2000). Introduction: Intellectual property on campus, computers, copyright, and cyberspace. Journal of College and University Law, 27(1).

Olivas, M. A. (2005). The legal environment: The implementation of legal change on campus. In P. G. Altbach, R. O. Berdahl, \& P. Gumport (Eds.), American higher education in the twenty-first century (pp. 226-252).

Baltimore, MD: John Hopkins University Press.

Olivas, M. A. (2013). Suing alma mater. Baltimore, MD: Johns Hopkins University Press.

Parthasarathy, S. (2014). Inventing democracy through the life form patent battles in the United States and Europe. Chicago, IL: University of Chicago Press.

Pauken, P. D. (2009). Intellectual property. In C. J. Russo (Ed.), Encyclopedia of law and higher education.

Thousand Oaks, CA: Sage, http://dx.doi.org.proxy.lib.umich.edu/10.4135/

9781412969024

Paulson, M. B., \& St John, E. P. (2002). Social class and college costs: Examining the financial nexus between college choice and persistence. Journal of Higher Education, 73(2), 189-236.

Raj, A. K. (2004). The increasingly proprietary nature of publicly funded biomedical research. In D. G. Stein (Ed.), Buying in or selling out? The commercialization of the American research university (pp. 117-126). New Brunswick, NJ: Rutgers University Press.

Rhoades, G. (1996). Reorganizing the faculty workforce for flexibility: Part-time professional labor. Journal of Higher Education, 67(6), 636-670.

Rhodes, F. T. (2001). The creation of the future: The role of the American university. Ithaca, NY: Cornell University Press.

Ross, S. (2012). Intellectual property policies in academe: Issues and concerns with digital scholarship. In B. R. Bernhardt, L. H. Hinds, \& K. T. Strauch (Eds.), Accentuate the positive: Charleston conference proceedings (pp. 397-400). West Lafayette, IN: Purdue University Press.

Roth, N. L., Sitkin, S. B., \& House, A. (1994). Stigma as a determinant of legalization. In S. B. Sitkin \& R. J. Bies (Eds.), The legalistic organization (pp. 137-168). Thousand Oaks, CA: Sage.

Saunders, D. B. (2010). Neoliberal ideology and public higher education in the United States. Journal for Critical Education Policy Studies, 8(1), 42-77.

Schacht, W. H. (2000). Patent ownership and federal research and development (R\&D): A discussion on the Bayh-Dole Act and the Stevenson-Wydler Act. Washington, DC: Congressional Research Service.

Schauer, F. (2006). Is there a right to academic freedom? Colorado Law Review, 77(4), 907.

Scott, W. R. (1994). Law and organizations. In S. B. Sitkin \& R. J. Bies (Eds.), The legalistic organization (pp. 3-18). Thousand Oaks, CA: Sage.

Selznick, P. (1969).Law, society, and industrial justice. New York, NY: Russell Sage Foundation.

Sitkin, S. B., \& Bies, R. J. (1993). The legalistic organization: Definitions, dimensions, and dilemmas. Organization Science, 4(3), 345-351.

Sitkin, S. B., \& Bies, R. J. (1994). The legalization of organizations: A multi-theoretical perspective. In S. B. Sitkin \& R. J. Bies (Eds.), The legalistic organization (pp. 19-49). Thousand Oaks, CA: Sage. Slaughter, S. (2001). Professional values and the allure of the market. Academe, 87(5), 22-26.

Slaughter, S., \& Leslie, L. L. (1997). Academic capitalism: Politics, policies, and the entrepreneurial university. Baltimore, MD: The John Hopkins University Press.

Slaughter, S., \& Rhoades, G. (2004). Academic capitalism and the new economy: Markets, state, and higher education. Baltimore, MD: The Johns Hopkins University Press.

Somers, P., \& Somers-Willett, S. B. (2002). Collateral damage: Faculty free speech in America after 9/11. Teachers College Record. http: / / www. tcrecod.org/ library ID Number: 11004.

Stevens, A. J. (2004). The enactment of Bayh-Dole. The Journal of Technology Transfer, 29(1), 93-99. doi:10.1023/B:JOTT.0000011183.40867.52.

This article is protected by copyright. All rights reserved. 
Stim, R. (2010). Getting permission: How to license \& clear copyrighted materials online \& off. Berkeley, CA: NOLO.

Suchman, M. C., \& Edelman, L. B. (1996). Legal rational myths: The new institutionalism and the law and society tradition. Law \& Social Inquiry, 21(4), 903-941.

Sun, J. C., \& Baez, B. (2009). Intellectual property in the information age: Knowledge as commodity and its legal implications for higher education. ASHE Higher Education Reporter (34), 4.

Tierney, W. G. (1998). Tenure is dead, long live tenure. In W. G. Tierney (Ed.), The responsive university: Restructuring for high performance (pp. 38-61). Baltimore, MD: The Johns Hopkins University Press.

Toma, J. D. (2011). Managing the entrepreneurial university: Legal issues and commercial realities. New York, NY: Routledge.

Warters, W. W. (1998). The history of campus mediation systems: Research and practice.

http://law.gsu.edu/cncr/pdf/papers/99-1Waterspap.pdf

Weber, M. (1947), The theory of social and economic organization. New York, NY: Free Press.

Weissmann v. Freeman, 684 F. Supp. 1248 (S.D.N.Y. 1988), rev'd 868 F.2d 1313 (2d Cir), cert. denied, 493

U.S. 883 (1989).

Welsh, J. F. (2000). Course ownership in a new technological context: The dynamics of problem definition. Journal of Higher Education, 668-699.

Yudof, M. G. (1981). Legalization of dispute resolution, distrust of authority, and organizational theory: Implementing due process for students in the public schools. Wisconsin Law Review, 1981 (5), 891-923.

Zusman, A. (2005). Challenges facing higher education in the twenty-first century. American higher education in the twenty-first century: Social, political, and economic challenges, 2, 115-160.

LARA K. BADKE holds a doctor of philosophy in higher education (2016) from the University of Michigan. Her work addresses complexities in higher education organization and management in relation to legal pressures. Lara also earned a juris doctor (1997) from the University of Windsor.

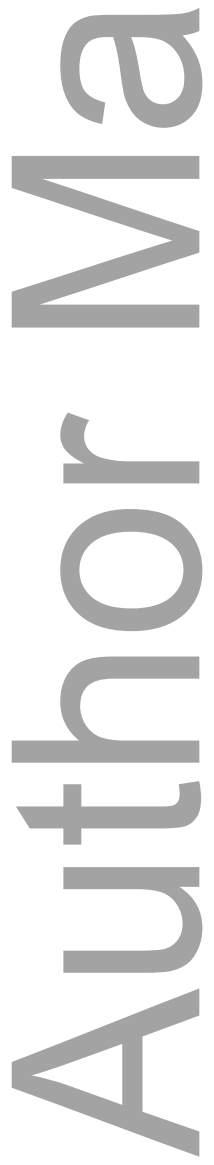

This article is protected by copyright. All rights reserved. 